\title{
The effect of telecollaboration in the development of the Learning to Learn competence in CLIL Teacher Training
}

\begin{abstract}
One of the main aims of diverse education systems is the development of key competences to improve citizens' capacity for lifelong learning. However, some authors have signalled the challenge their measurement entails, among them the Learning to Learn (LtL) competence, which has also been shown to be complex to define and is under researched. With a pre-post-test design and a variety of assessment instruments, this study compares the effect having an educational technology course and using telecollaboration has on the development of the LtL competence in a content and language integrated (CLIL) learning environment. Four groups of teacher trainees at two different universities took initial and after treatment surveys on LtL. Quantitative and qualitative data analysis indicated that technology boosts LtL but that telecollaboration helps develop LtL reflective concepts further in the form of processes by constructing or accomplishing learning goals in similar contexts.
\end{abstract}

Keywords: preservice teacher education; telecollaboration; CLIL; reflective practice; learning to learn; ICT

\section{Introduction}

For decades, education systems have been requested to develop the eight key competences for lifelong learning described as "the combination of knowledge, skills and attitudes appropriate to the context which all individuals need for personal fulfilment and development, active citizenship, social inclusion and employment" (Council, 2018).

However, different authors (Hoskins \& Fredriksson, 2008) have already signalled the challenge the measurement of some of those competences entails. Personal, social and learning to learn competence, hereinafter referred to as "LtL" following the European Commission (2012) assessment of key competences, is one of the competences that has been shown to be complex to define and measure as it seems to include very different areas such as metacognition, thinking skills and strategies, as well as diverse dispositions, 
attitudes and beliefs (Fredriksson, 2013). As the competence includes three subcompetences which entail different skills, knowledge and abilities, this paper will focus on one of them: learning to learn (LtL). Previous research on LtL includes efforts focusing on testing cross-curricular skills (Meijer, Elshout-Mohr \& Van Hout-Wolters, 2001), evaluating metacognitive skills (Moreno, 2006) or creating an effective Lifelong Learning Inventory (Deakin-Crick, Broadfoot \& Claxton, 2006). And even though Mesárosova and Mesáros (2012) have highlighted LtL predictive influence on other academic competences, research on it remains scarce.

Providing student teachers with the necessary skills to teach and develop this key competence seems essential to ensure that future teachers can articulate effective plans to give a response to the ever-changing competences demanded by society. It seems paramount to explore its development in teaching practices so that it becomes an integral part of teachers' initial training (Martín, 1998; Moreno \& Martín, 2014).

Consequently, this project aims to continue research on LtL in teacher education by measuring its evolution based on Fredrickson's (2013) framework, which covered parts of learning to learn thinking skills and strategies, including learning to learn beliefs, dispositions and attitudes scales. It is also based on the studies on LtL testing carried out by Hautamäki et al. (2002: 41), which consider that assessing learning to learn "comprises various domains of skills and abilities that can be divided into cognitive skills and abilities and affective control skills and abilities".

Telecollaboration, which "can be defined as a learner-centred activity that entails engaging students in virtual collaboration with partners in different locations in order to achieve certain learning or training goals" (Vinagre, 2017: 35), has been reported to afford the opportunity to widen the scope of pre-service and in-service teachers' knowledge and to raise their awareness about effective ICT use by having them 
collaborate with others and justify their methodological and technological choices in their lesson plan designs (Author 3, Author $2 \&$ Author 1, 2018; Vinagre, 2010). This study seeks to assess the effect using telecollaboration might have on the development of the LtL competence of teacher trainees.

\section{Literature review}

\section{Learning to learn competence}

Despite the fact that different initiatives have focused on building teachers' capacity to develop competence oriented education to improve teachers' awareness and assessment of those key competences (Häutamaki et al., 2002; Sendova \& Stefanov, 2009; TLRP, 2017), scarce research has focused on this particular competence due to the difficulty of measuring it and of analysing any impact interventions might have on it (Hoskins \& Fredriksson, 2008). Yet, its development has been considered quintessential for lifelong learning (Fredriksson \& Hoskins, 2007; Hoskins \& Fredriksson, 2008), a fundamental skill in the ever-changing knowledge-based society.

LtL competence refers to a person's ability to advance in their life and work as a result of self-initiated, self-regulated and intentional learning in which the capacity to control one's own thinking and learning processes, referred to as the metacognitive competence, is underscored (Eurydice, 2002). Many authors have also related LtL to metacognition (Bakracevic, 2006) and metalearning (Moreno, 2006) whereby knowledge about how one learns, about one's own learning, thinking and acting as well as about how to learn is obtained (Sorenson, 2006).

The fact that LtL skills do not seem to improve as students complete higher courses at university (Muñoz-San Roque, Martín-Alonso, Prieto-Navarro, and Urosa- 
Sanz, 2016) stresses the need to include new ways of developing that skill at university and, especially, in teacher training programs.

\section{Teaching English as a Foreign Language in Teacher training}

Content and language integrated learning (CLIL) is considered a current approach in which a foreign language is used for the teaching of non-language subjects (Coyle, 2005) and educationalists believe that it also contributes to the enhancement of thinking processes, creative and critical thinking skills (Hanesova, 2014; Nieto, 2016; Novotná \& Hofmannová, 2016). However, the professional competences of CLIL teachers together with the attitudes and professional skills needed for teaching are still being reviewed and redefined (Marsh, Mehisto, Wolff \& Frigols Martín, 2010).

ICT has the potential to engage students in a range of activities that contribute to critical thinking development and collaborative knowledge construction (Wang, Woo \& Zhao, 2009:95) and can help develop material for courses on content and language integrated learning provided that "task-type online situations can influence reflection and higher order thinking" (Dooly \& Sadler, 2013:6). Furthermore, as stated by Garcia Laborda \& Author 1 (2017), the use of specific technologies such as computer-mediated telecollaboration can serve as support for analysis through teacher-instructor interaction, as a means of social interaction. ICT can be used to force students to work in a collaborative environment where thinking, working and solving problems is a must through cooperative dialogue (Author $3 \&$ Author 1, 2016). Students can learn how to “explore, think and solve problems" (Hanesová, 2014:34) by setting activities that can stretch their thinking and help them move into higher order cognitive processes. Furthermore, using virtual collaboration, pre-service teachers are forced to explore the affordances of ICT (Kleban \& Author 3, 2015) and they are offered opportunities to 
increase their digital teaching competence (Author 3, Author 2 \& Author 1, 2018; Author 1, 2017).

\section{Telecollaboration and the development of competences}

There has been a surge of research interest in the use of telecollaboration to integrate technology into courses (Guth, Helm \& O’Dowd, 2012; Schmidt \& Hegelheimer, 2014) to aid in the development of some of the competences established by the Council (2006) as objectives to promote lifelong learning. Telecollaboration has been analysed both to develop linguistic development and communicative competence in the foreign language classroom (Author 3, 2010, 2013).

However, only recently, telecollaboration has started to be explored as a way to improve teacher training courses (Grosbois, 2011). The results of those projects have been quite promising as future teachers have been reported to experience an increase in their digital competence (Author 3 \& Kleban, 2016; Schmidt \& Hegelheimer, 2014), and the development of multimodal communicative competence, multiliteracy, autonomy, and the teacher competences required for teaching with multimodal technologies (Fuchs, Hauck \& Müller-Hartmann, 2012). Furthermore, these kinds of projects increase preservice teachers' awareness of the affordances some technologies might have for teaching and also improve their capacity to solve problems (Guichon, 2009; Hampel, 2009). The outcomes of those studies have also shown that educators do not ponder enough about how technology can help students to actively construct their knowledge (Dooly, 2013), and student teachers should be encouraged to reflect on how telecollaboration can be contextualized so that they can see the relevance of what they are learning and how they learn (Dooly, 2010). This reflection process about their own learning that can be 
enhanced by using telecollaboration together with an increase in their capacity to solve the problems they might encounter while carrying out the telecollaboration might help improve their LtL competence.

\section{Materials and method}

\section{Aim of the study and research questions}

This preliminary study was designed to compare the effect that telecollaboration might have on the improvement of pre-service teachers' LtL competence in order to evaluate whether this resource could enhance the development of this key competence in preservice education. The following research questions were considered as a guide for the analysis:

(1) Does an educational technology course have any effect on the development of the LtL competence?

(2) Does telecollaboration aid in the improvement of the LtL competence?

(3) Which contributes the most to the improvement of LtL competence: an ICT course or an ICT course with telecollaboration?

\section{Participants}

The participants were four groups of pre-service teachers doing their final year in a Degree of Primary Education. Two groups $(n=38)$ belonged to Cardenal Cisneros University Center (CUCC, University of Alcalá) and two other groups (n=62) were from the Public University of Navarre (UPNA) in Spain. Two of the groups from each institution were the control groups $(\mathrm{n}=53)$, and the remaining two were the experimental groups $(n=47)$. All the students from both locations were taking a course on CLIL; the two groups from UPNA had an additional specific course on Educational Technology. 
Both control and experimental groups received instruction on how to create CLIL units and were required to design one in groups using technological resources

In the control groups, teachers and students met in face-to-face lessons, but some tasks were required to be completed online working in small groups outside the classroom. Both control groups received instruction on how to create CLIL units and had to create one in groups using technological resources. The UPNA group also received a full course on ICT as part of their degree instruction throughout the project. In the experimental groups, the students were involved in a telecollaboration project which consisted in two telecollaborative exchanges and the same series of face-to-face tasks using technology as the control group. Apart from the regular work they had to do, the participants in the experimental groups, using telecollaboration, discussed the improvements and changes to be made to the unit they had created in order to improve the development of high order thinking skills (HOTS) from Bloom's taxonomy and the use of technology with the group of students in the other location. The collaborative tasks the students in the experimental group carried out were designed following O'Dowd and Ware's (2009) collaborative task category, "which requires learners not only to exchange and compare information but also to work together to produce a joint product or conclusion" (Vinagre, 2016:175) and were aimed at fostering information exchange, discussion, and reflection based in the contents of the blog and a wiki space that had to be created and designed cooperatively by all group members. A summary of the tasks is provided in Appendix 1.

\section{Instruments}

Three instruments were used for data collection: (i) a LtL pre-treatment questionnaire; (ii) a LtL post-treatment questionnaire; and (iii) a reflection essay. The pre and post 
questionnaires (taken from European Commission, 2017) were identical and they included 16 closed-ended items (see Appendix 2) where students had to rate, on a scale from Level 1 to Level 4, their perceived LtL Competence Knowledge. The questionnaires divided LtL into four areas: Why I learn; which involved a justification of the student's learning motivation, What I learn, dealing with setting objectives and planning activities; How I learn; addressing to the organized and targeted learning activities, Reflection on progress; which involved a reflection on the learning activities and outcomes. Each of those areas was divided into four levels (L1 to L4), which went from the lowest level of competence, level 1, to the highest possible level, level 4. Each of the levels included a descriptor.

In the reflection essays, students were asked about the courses (control group), and about the courses and the telecollaborative experience (experimental group).

\section{Procedure and data collection}

At the beginning and at the end of the term, students in all groups were asked to complete the LtL questionnaires. At the end of the term, the four groups were also asked to hand in reflection essays.

Quantitative data were collected from the self-assessment pre and post questionnaires. The data were organized in tables and percentages of students selecting each level in the pre and the post-tests were compared using descriptive statistics. Students were separated by location to explore further differences depending on ICT knowledge. No inferential statistics were used because means would not illustrate the evolution of students' perceived level of competence appropriately.

Qualitative data were gathered from the self-evaluation essays. Students' opinions were gathered and recurrent themes identified. Comments from those recurrent themes 
were used to support some of the quantitative data observed. Direct quotes in brackets will document local experiences and provide evidence of the views and concerns stated by the participants.

\section{Results and discussion}

\section{Enhancement of LtL competence with ICT}

According to the quantitative data that can be seen in Table 1, doing a course on CLIL alone, or a course on CLIL plus ICT, and creating a didactic CLIL unit did not highly modify the LtL competence of teacher trainees. Upgrading was detected in Level 1 (CUCC) and Level 3 (UPNA) of the four areas of knowledge analysed: What I learn, How I learn, Why I learn and Reflection. Modest advances in the development of the highest cognitive Level 4 were detected in the CUCC group, while UPNA students showed advances at Level 4 in two of the areas: What I learn and Reflection.

UPNA student teachers showed improvements at Level 3 of two areas: What I learn, where they experienced an increase of $31,9 \%$ (from $41,4 \%$ to a $73.3 \%$ ), and How I learn, where they experienced an improvement of $19,6 \%$ (from $53,8 \%$ to $73.4 \%$ ). They also experienced an improvement of $17,1 \%$ (from $29,6 \%$ to $46,7 \%$ ) at Level 4 of the fourth area Reflection. CUCC group main increase was $21,8 \%$ (from $4 \%$ to $25,8 \%$ ) at Level 1 of the first area Why I learn by selecting that "I learn when others urge, encourage or persuade me. I feel secure when somebody helps me. When I work together with others, I observe more often how others are doing things". Student teachers did not reveal any upgrade concerning Level 4 on learning motivation and goal settings, particularly CUCC students, who decreased their perception of being at Level 4 of the four areas. 
Table 1: Control groups (CG): CUCC vs UPNA

\begin{tabular}{|c|c|c|c|c|c|c|}
\hline & & & Why I learn & What I learn & How I learn & Reflection \\
\hline \multirow[t]{4}{*}{ EVVEL 1} & \multirow[t]{2}{*}{ pre-test } & CG-CUCC & $4.0 \%$ & $0.0 \%$ & $0.0 \%$ & $4.2 \%$ \\
\hline & & CG-UPNA & $3.7 \%$ & $3.4 \%$ & $3.8 \%$ & $7.4 \%$ \\
\hline & \multirow[t]{2}{*}{ post-tes } & CG-CUCC & $25,8 \%$ & $12.5 \%$ & $15.6 \%$ & $12.9 \%$ \\
\hline & & CG-UPNA & $0 \%$ & $0.0 \%$ & $6.7 \%$ & $0.0 \%$ \\
\hline \multirow[t]{4}{*}{ EEVEL 2} & \multirow[t]{2}{*}{ pre-test } & CG-CUCC & $8.0 \%$ & $22.7 \%$ & $17.4 \%$ & $16.7 \%$ \\
\hline & & CG-UPNA & $7.4 \%$ & $20.7 \%$ & $26.9 \%$ & $7.4 \%$ \\
\hline & \multirow[t]{2}{*}{ post-test } & CG-CUCC & $9.7 \%$ & $15.6 \%$ & $9.4 \%$ & $19.4 \%$ \\
\hline & & CG-UPNA & $12.5 \%$ & $0.0 \%$ & $0.0 \%$ & $0.0 \%$ \\
\hline \multirow[t]{4}{*}{ EVEL 3} & \multirow[t]{2}{*}{ pre-test } & CG-CUCC & $40.0 \%$ & $36.4 \%$ & $56.5 \%$ & $33.3 \%$ \\
\hline & & CG-UPNA & $37.0 \%$ & $41.4 \%$ & $53.8 \%$ & $55.6 \%$ \\
\hline & \multirow[t]{2}{*}{ post-test } & CG-CUCC & $32.3 \%$ & $40.6 \%$ & $56.6 \%$ & $41.9 \%$ \\
\hline & & CG-UPNA & $43.8 \%$ & $73.3 \%$ & $73.3 \%$ & $53.3 \%$ \\
\hline \multirow[t]{4}{*}{ EVEL 4} & \multirow[t]{2}{*}{ pre-test } & CG-CUCC & $48.0 \%$ & $40.9 \%$ & $26.1 \%$ & $45.8 \%$ \\
\hline & & CG-UPNA & $51.9 \%$ & $34.5 \%$ & $15.4 \%$ & $29.6 \%$ \\
\hline & \multirow[t]{2}{*}{ post-test } & CG-CUCC & $32.3 \%$ & $31.3 \%$ & $18.8 \%$ & $25.8 \%$ \\
\hline & & CG-UPNA & $43.8 \%$ & $26.7 \%$ & $20.0 \%$ & $46.7 \%$ \\
\hline
\end{tabular}

Similarities and differences between those students who had taken the CLIL course, the control group from CUCC, or the CLIL course plus an ICT course, the control group from UPNA, generally showed increases at the lowest levels of their LtL competence in detriment to the second level, and some increases at Level 3 coupled with modest or no advances at the highest levels.

Attending to the posttest results of the first area, Why I learn, most students manifested "a need in seeking and making use of guidance, motivation and confidence in learning”, which is one of the principles of the LtL competence (Fredriksson, 2013). In this sense, LtL offers pupils awareness of how they prefer to learn and their learning strengths, how they can motivate themselves and have the self-confidence to succeed 
(The Campaign for Learning, 2007). The lack of improvement of this indicator at the end of the CLIL course may suggest the necessity for teachers to provide clear frameworks, feedback and stimuli to successfully develop this approach in teaching English as a foreign language.

Referring to the second area What I learn, both groups stated that they tried to set their learning goals and plan their learning activities usually adhering to the schedule. After the CLIL course or the CLIL plus ICT courses, both groups recognised being unable to complete most tasks on time and admitted consulting others when setting the learning goals, above all the UPNA group. This reflection may contribute to the development of the LtL competence according to Fredriksson's (2013) principle that the acquisition of this competence involves organising one's own learning, including effective management of time and information. This is in accordance with Coyle's (2005, 10) observation that effective frameworks -such as the $4 \mathrm{Cs} / 3$ Planning tool- need to be used, explored, adapted and reformulated according to different contexts in order to effectively plan and monitor learning processes and lesson planning. Following specific guides might have helped students achieve their aims and schedules.

Regarding the third area How I learn, all groups -moreover UPNA- indicated initially their preference to decide the learning methods, tools, and information sources and how to perform certain tasks with external help. However, in the post-questionnaire, students admitted trying to use different learning methods and the required learning tools in advance by themselves, except CUCC students, who revealed not having achieved this. This action involved the conception of learning to learn "as a process of discovery about learning comprising a set of principles and skills which, if understood and used, can help learners learn more effectively and so become learners for life" (Campaign for Learning, 
2007). Although the course on CLIL involved planning for effective integration of content and language as well as discussing guiding principles and tools for learning (Coyle, 2005), it seemed insufficient for all the student teachers.

Concerning the last area Reflection on learning, after the CLIL experience and their reflection essays, student teachers acknowledged to autonomously reflect on how and what they achieved in learning. However, whereas UPNA students admitted to plan in what areas and how they could improve by themselves, CUCC students revealed doing it mostly with external help. This idea has to do with McCormick (2006) self-regulation learning to learn mechanisms for evaluating and revising strategies and Fredriksson's (2013) concept of developing awareness of one's learning process and the need of identifying available opportunities. These results justify that "effective learning involves cognitive challenge and feedback -assessment for learning", as stated by Coyle (2005:9) and, therefore, the necessity to make materials accessible for students, especially when the concepts are difficult following Sharma and Hannafin's (2007:43) indication that "scaffolding needs to be consistent with students' understanding and cognitive development". This difference between groups might be attributed to the use of different resources - such as the technological ones instructed in the UPNA -, as learning how to use technology effectively might have some impact on more autonomous forms of learning.

\section{Enhancement of LtL with telecollaboration}

Contrary to the limited improvements experienced by students with regard to Level 4 in the four areas when they had followed only courses on CLIL and educational technology, more positive results related to the acquisition of the LtL competence were found when telecollaboration was introduced. 
Figure 1: Experimental groups (EG): CUCC vs UPNA

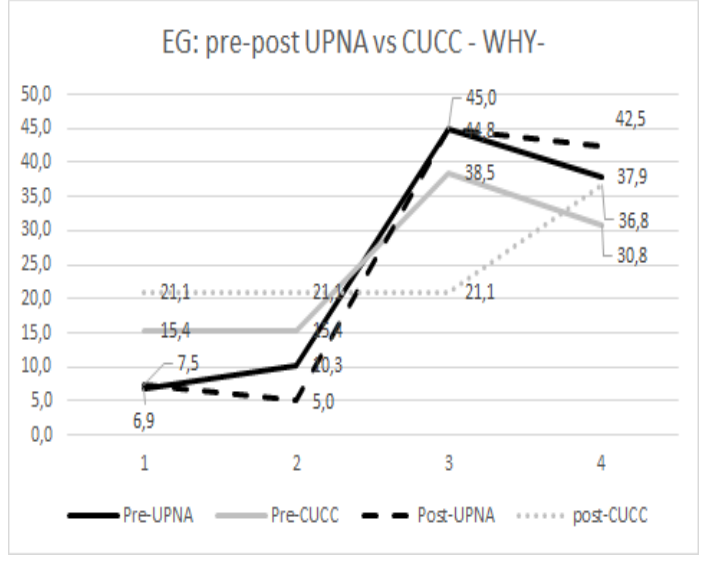

EG: Pre-postUPNAvs CUCC - HOW

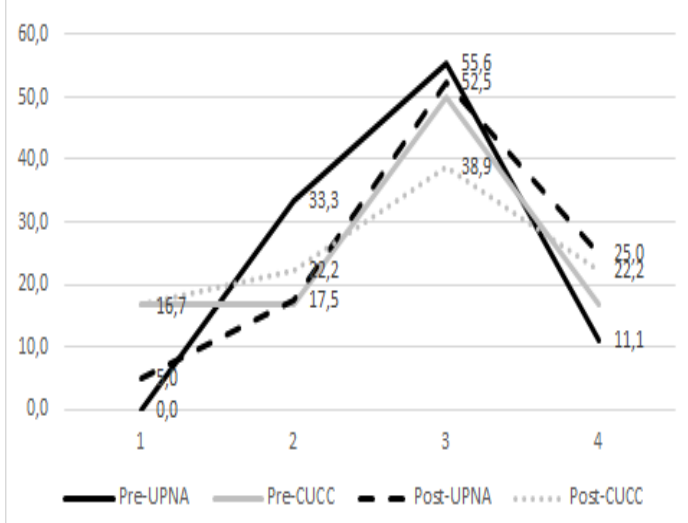

EG: PRE-POST UPNA vs CUCC - WHAT-

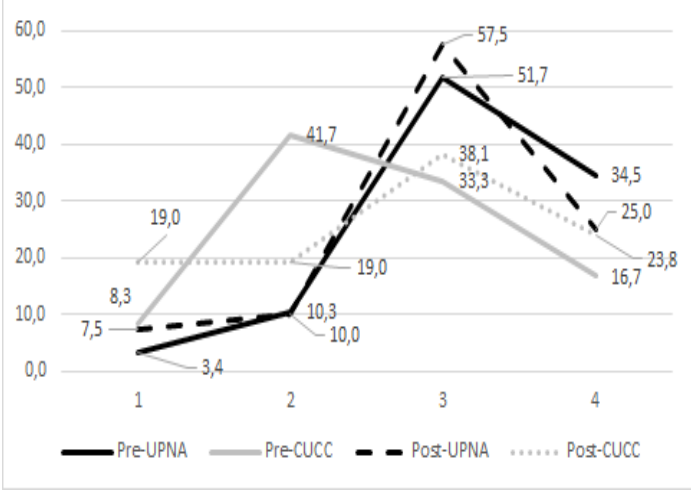

EG: Pre-post UPNAvs CUCC - Reflection-

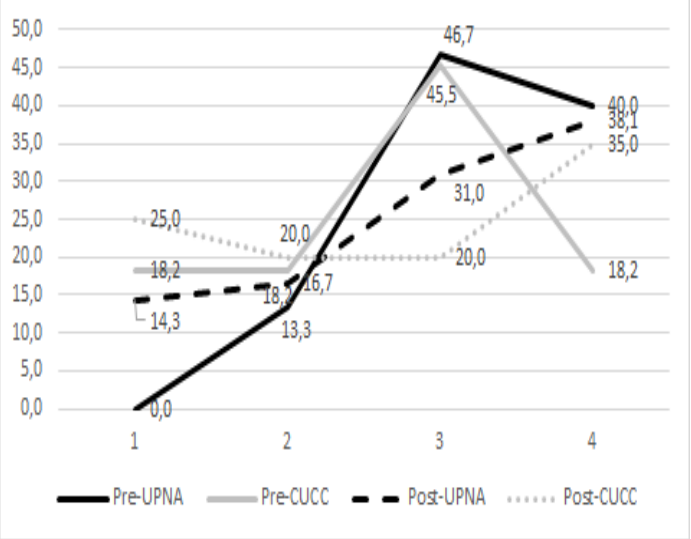

As can be seen in Figure 1, both experimental groups showed a slight overall development of the LtL competence $(+15 \%$ average) after carrying out the proposed CLIL reflective tasks using virtual collaboration. The CUCC group showed improvements in 11 of the levels; the UPNA group in 8 out of the 16 possible levels. The UPNA student teachers demonstrated an advance in several particular levels and categories, whereas CUCC showed an improvement in all the categories of Level 4. Less progress was shown at level 3 by the CUCC group in the areas Why I learn? How I learn? and Reflection on progress. Referring to the first area, Why I learn, after the telecollaborative exchange, in the post-questionnaire, $+17,4 \%$ of student teachers revealed that they felt less self-confident when they had to perform new tasks because of making mistakes. About the second area How I learn?, $+11,5 \%$ of participants manifested 
that they had not used different learning methods nor information sources or learning tools when planning the tasks. Finally, $+25,5 \%$ of students admitted being helped by others to plan what areas and how they should improve.

Concerning the first area related to motivation (Why I learn), both universities revealed an improvement in the highest levels, except for the CUCC group, which showed a decrease in Level 3. That means that whereas after the telecollaboration some of the CUCC students perceived learning as a duty: “GA_2.I think for the work involved we should get more credit (higher mark)", most students acknowledged that they learnt eagerly and responsibly because they liked learning and understood that what they learnt will serve them in the future:

"GB_4 GA_4 I learn ICT skills that will be important and valid in the future,, this activity will help in my future as a teacher in a class of Primary",

GA_4 we need more training in TICS because they are increasingly present in schools GB_5 I have liked to be able to take part very much in this project to improve communication in English.

Despite the overall progress, results concerning setting objectives and planning activities (What I learn) differed between universities. CUCC students acknowledged to consult others when setting their learning goals and plan their learning activities: "GA_4 Group work must be facilitated to exchange and share ideas" (L2). After the telecollaboration, they admitted being able to set their learning goals and plan their learning activities autonomously "GA_4 I have learnt to plan activities with TICs" in opposition to the UPNA students (L4). UPNA participants rated higher at Level 3 stating that they usually managed to adhere to the schedule and complete the set tasks on time.

General improvement was perceived in the organized and targeted learning activities (How I learn) for all groups, specifically for the CUCC group. Despite the fact 
that most UPNA student teachers pointed out their initial preference to decide learning methods and tools with external support (L2, L3), at the end of the virtual exchange they succeeded in obtaining any required learning tools in advance by themselves: (L4) "GB_4 you must act well and prepare the class with time and patience".

Finally, a global advance was achieved in Reflection on learning for CUCC students:

"GA_2 I have learned a lot and I've noticed that sometimes it's difficult to adapt a theme to a lower level than to a higher one".

GA_2.we have also learnt different TIC, I have learned to record and edit videos, to play music and videos in a PowerPoint"

The initial remark of the UPNA students in L3 of Reflection meaning that they needed external help to reflect on how and what to achieve in learning and in what areas to improve was not altered after the telecollaboration in L4: "GB_5 I liked to work (telecollaboratively) with others contents related to the methodology CLIL".

Enhancement of LtL with telecollaboration vs ICT educational course

After exploring the impact of working cognitive reflections on CLIL learning with and without telecollaborative exchanges by university students, this section analyses to what extent telecollaboration contributes to the development of the Learning to learn competence by comparing the outcomes between the experimental groups and those students who had not used telecollaboration in the CLIL course.

Results in Figure 2 indicate a moderate improvement of both universities in all the categories up to $\mathrm{a}+12,6 \%$ at Level 2 of the third area How I learn in the control group. 
Figure 2. CG \& EG PRE-POST TEST
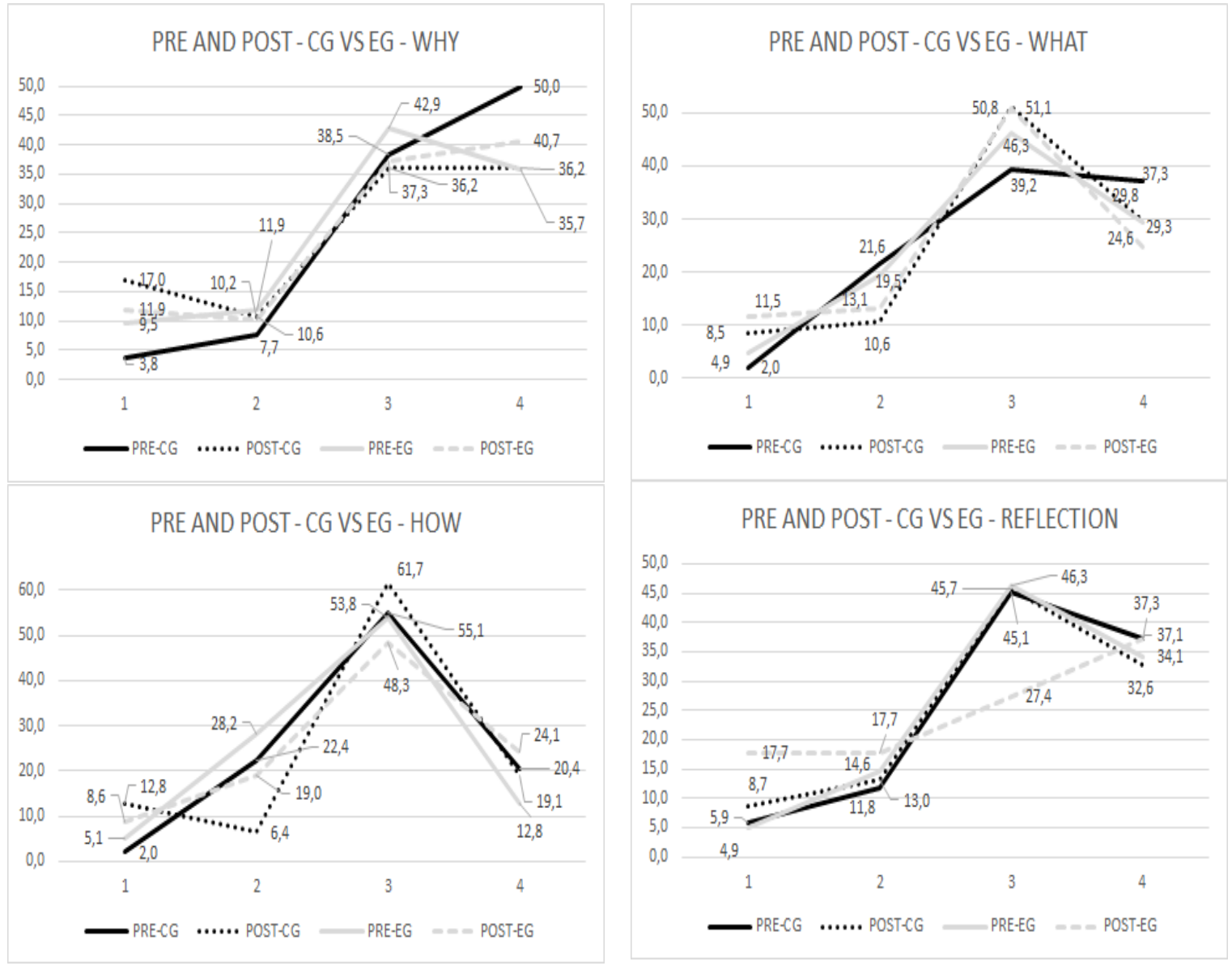

Initially, the assessment from the untested experimental group rated lower than the control group outcomes in all the categories from level 4. After the telecollaborative experience, the post-questionnaires indicated that the experimental groups, both from CUCC and UPNA, slightly overpassed $(+5 \%)$ the results of the control groups except in What I learn? category, which indicated a negative 5\% rate.

In line with the outcomes in the previous sections, the main decrease took place in level 3 categories "How I learn?" (-13,4\%) and "Reflection on progress" (-18,3\%), as the results of the EG post-survey displayed.

Concerning motivation, (Why I Learn), data revealed that telecollaboration slightly enhanced the highest level (L4) of the LtL competence. After the 
telecollaboration (TC) learning experience, student teachers acknowledged responsible learning and to care for the need of being appropriately qualified for the future: "GA_4 I learn ICT skills that will be important and valid in the future”. Results seemed to confirm that the inclusion of technology in the classroom involved a collaborative encouraging educative challenge: "GA_2: We have worked much more motivated, which has made the work not so heavy". This might be due to the fact that TC helps students' intergroup interactions and this cooperation facilitates the co-construction of meanings (Tanghe \& Park, 2016).

As shown in the data gathered, TC did not allow students set objectives and planning (What) at the highest level but just attempt to do it (L3) due to different arguments such as "GA_2 the content is very broad and we have had very little time". This fact implicitly involved awareness of self-achievement and the need of planning in teacher training provided that "learning in an online environment supports open communication including recognition of each other's contributions" (Arnold and Ducate, 2006:47), thus contributing to the development of the LtL competence for the activation of self-regulating mechanisms (planning what to do, checking outcomes of strategies, evaluating and revising strategies) as defined by McCormick (2006).

Results seem to confirm the enhancement (L4) of the LtL (How) at the end of the TC experience by encouraging the use of different methodologies, resources and learning activities: “GB_5 (I liked to) work (online) with other students different methodological contents related to CLIL". These findings coincide with Warschauer, Turbee, and Roberts' idea that the appropriate and effective use of computer networks is partly a technical issue, but primarily a pedagogical one (1996:9).

TC appeared to develop reflection on learning activities and outcomes, and selfassessment: "GB_4 we can advise improvements to do better the next time" based on the 
concept that collaboration in an online environment creates the opportunity for a group of people to construct knowledge together, thus linking reflection and interaction" (Arnold \& Ducate, 2006:44).

Based on our findings, data showed a low positive trend towards the improvement of our student teachers LtL competence after the telecollaborative exchange at the highest level but in a small proportion. Despite the fact that higher cognitive gains would have been desirable, results led us to consider that the TC task had a stronger influence than taking a course on ICT, probably due to the experiential learning that boosted metacognition.

Taking into account that the definition of $\mathrm{LtL}$ is embedded in social relationship and the social context referring to group work, 'seeking and making use of guidance' and building on 'life experiences' (Fredriksson, 2008), telecollaboration seems to help develop this key competence, but not as much as expected. However, considering the difficulty of modifying beliefs and self-efficacy concepts, even a small improvement in the highest levels of competence can be considered a success. It should also be taken into consideration that both Level 3 and 4 improved and so students experienced an improvement of the competence from lower levels to higher levels.

\section{Conclusions}

Considering the quantitative and qualitative findings of our research project, technology appears to generally support LtL competence in teacher training for the development of cognition by providing awareness and knowledge of certain aspects, although not consistently across levels and categories. Notwithstanding this, telecollaboration seems to enhance metacognition further than an ICT course probably through the social situation it involves, which according to student teachers' perceptions makes them feel more self- 
confident, not be afraid of challenges and be willing to carry out new tasks when working together with others (Why). By sharing their experiences and providing feedback to one another, students seem to slightly improve and acquire hands-on understanding of specific concepts such as using different learning methods and specific learning tools (How). Online peer support also helps to autonomously reflect on how and what can be achieved in learning (Reflection on learning). Strategies for setting learning goals and activities adhering to the schedule (What) seem not to be enhanced by telecollaboration, an aspect to be taken into account by instructors.

Telecollaboration appears to enhance all the categories of LtL competence in CUCC students, moreover the one concerning reflection on what they had achieved in learning and how to improve. On the contrary, virtual collaboration did not seem to improve the reflection on learning for UPNA students nor helped setting their learning goals autonomously to complete tasks on time. This might be due to the fact that Navarre students were more used to working with technology -and collaborative networks- as a course of educational technology was included in their curriculum.

Results have shown that TC helps develop LtL reflective abstraction in the form of processes -such as control of teaching variables and planning- by constructing and/or accomplishing learning goals in similar contexts.

In general, data support the idea that telecollaboration can help student teachers be aware of the relevance of how they learn.-The slight percentile differences in the current project, however, suggest that despite the fact that TC might raise awareness of What is being learnt, other high-cognitive challenge tasks such as the ones commonly involved in CLIL based teaching can also help boost this cognitive account.

These outcomes also confirm Author 3 and Author 1's (2016) findings on the potential of telecollaboration in the field of teacher training for the development of 
techno-pedagogical-content skills in dialogic practices. Virtual exchanges seem to facilitate the experiential and authentic use of technology by engaging pre-service teachers in cognitive training which affords them the opportunity to be creators of knowledge by way of active collaboration and reflection (Author 3, Author $2 \&$ Author, 1; Author 3 \& Kleban, 2016).

All in all, telecollaboration seems to support Stringher (2006) paradigms for the development of LtL as it helps activating 1) the cognitive psychology paradigm enhancing the mechanisms used to internalise knowledge and the social paradigm (with the student as the agent of learning and by the application of experiential learning and meaningful learning co-construction) and 2) the learning embedded definition (ability to access, gain, process and assimilate new knowledge and skills, followed by the ability to reflect critically on the purposes and aims of learning).

Probably, future research should follow up on work by Gargallo et al. (2016) and explore different possibilities or attempts that can be made to help students develop their LtL which include the application of specific programmes, the design of open attendance subjects or workshops for students, or the inclusion of self-regulated learning in the programme. Yet, our students might have experienced inductively many of the components of the LtL through the virtual task they had to carry out, although it might be the case that our students would have benefited more from the experience if combined with a deductive explanation of the dimensions of the LtL. The theoretical and experiential knowledge acquired would allow students to reflect on their LtL practices.

This study has some shortcomings that should be acknowledged. First, the novelty of the project might have affected the ranking students provided. They might have responded more positively to the post telecollaboration questions because it was a new task for them and thus lack of novelty could lead to a waning of the benefits. 
Additionally, further research should explore in greater depth how a longer telecollaboration affects $\mathrm{LtL}$ competence and whether gains in that competence are reflected in how learners carry out tasks. It might be the case that students report a level which can not be confirmed by observations, and so observations of performance are also needed. The qualitative responses of the participants should also be further analysed targeting the various categories addressed quantitatively. Finally, it is also unclear whether a different type of ICT course would yield similar results. Therefore, results need to be taken with caution and further research should be carried out to confirm the findings in different contexts.

\section{Funding acknowledgments}

This work was supported by the Spanish Ministry of Economy and Competitiveness under Grant EDU2014-54673-R.

\section{References}

Arnold, N., and Ducate, L. (2006). "Future foreign language teachers' social and cognitive collaboration in an online environment". Language Learning \& Technology, 10, 42-66.

Author 1, (2017). Do Video LOs Develop Digital Competence in CLIL Teacher Training?” RAEL: Revista Electrónica de Lingüística Aplicada 16 (1), 85-102.

Author 3, (2009). Using WebCT in a course of English for academic/specific purposes: The case of English for agriculture. Teaching academic and professional English online, 127-152. Frankfurt: Peter Lang.

Author 3, (2010). Synchronous-voice computer-mediated communication: Effects on pronunciation. CALICO Journal 28(1), 1-20. 
Author 3, (2013). Interactional feedback in synchronous voice-based computer mediated communication: Effect of dyad. System, 41(3), 543-559.

Author 3 and Kleban, M. (2016). Matching linguistic and pedagogical objectives in a telecollaboration project: a case study. Computer Assisted Language Learning 29(1), 148-166.

Author 3 and Author 1, (2016). Telecollaboration to Improve CLIL and TPACK Knowledge: Aid or Hindrance?. Estudios sobre Educación, 31, 117. https://doi.org/10.15581/004.31.117-138.

Author 3, Author 2, and Author 1, (2018). Can telecollaboration contribute to the TPACK development of pre-service teachers?. Technology, Pedagogy and Education, 1-14. https://doi.org/10.1080/1475939X.2018.1471000.

Bakracevic, V. (2006). Research on learning to learn. Learning to learn network meeting Report from the second meeting of the network. Ispra: CRELL/JCR.

Bentley, K., (2010). The TKT Course CLIL Module. Cambridge: CUP.

Brigido-Corachan, A.M., (2009). From the virtual forum to the classroom: Developing cognitive engagement and critical thinking skills through online and face-to-face student discussions. Lenguaje y Textos 29, 141-153.

Campaign for Learning (2007). What is learning to learn? London. Retrieved from: http://www.campaignforlearning.org.uk/projects/L2L/What\%20is/What\%20is\%20L2L.htm.

Council, E., (2006). Recommendation of the European Parliament and the Council of 18 December, 2006 on Key Competencies for Lifelong Learning. Brussels: Official Journal of the European Union 30 (12), 10-18. 
Council, E. (2018). Council Recommendation on Key Competences for Lifelong Learning. Brussels. Retrieved from: https://eur-lex.europa.eu/legalcontent/EN/TXT/?qid=1527150680700\&uri=CONSIL:ST_9009_2018_INIT

Coyle, D. (2005). Developing CLIL: Towards a theory of practice. APAC: Barcelona.

Deakin Crick, R., Broadfoot, A. \& Claxton, G. (2006). What is the ELLI Research Project? Retrieved from: http://www.ellionline.co.uk/research.php.

Dooly, M., (2010). Empowering language minorities through technology: which way to Go?. E-learning Papers, 19, 1-12.

Dooly, M., (2013). Focusing on the social: research into the distributed knowledge of novice teachers in online exchange. In Online teaching and learning: sociocultural perspectives. Advances in digital language learning and teaching, edited by $\mathrm{C}$. Meskill, 1-30. London/New York: Bloomsbury Academic.

Eurydice, (2002). Key competencies: A developing concept in general compulsory education. Brussels: Eurydice/European Commission.

European Commission, (2006). Recommendation of the European Parliament and of the Council of 18 December, 2006 on key competences for lifelong learning. Retrieved from: http://enil.ceris.cnr.it/Basili/EnIL/gateway/europe/EUkeycompetences.htm

European Commission, (2012). Education and Training, 2020 Work programme Thematic Working Group 'Assessment of Key Competences. Retrieved from: http://ec.europa.eu/dgs/education_culture/repository/education/policy/school/doc/key review_en.pdf.

European Commission, (2017). Report on a literature review of reforms related to the, 2006 European Framework of Key Competences for lifelong learning and the role of the Framework in these reforms. Luxembourg: Publications Office of the European 
Union. Retrieved from: https://ec.europa.eu/education/sites/education/files/keycompetences-consultation-2017-strategy_en.pdf.

Fredriksson, U., (2013). Learning to learn - what is it and can it be measured?. Retrieved from: https://curriculumredesign.org/.../L2L-Paris-14-15-October-CompatibilityMode.pdf

Fredriksson, U. \& Hoskins, B. (Eds.) (2007). The Curriculum Journal. Special Issue in Learning to Learn. 18 (2).

Fredriksson, U., \& B. Hoskins B. (2008). Learning to learn: What is it and can it be measured? Ispra: European Commission JRC.

Fuchs, C., Hauck, M. \& Müller-Hartmann, A. (2012). Promoting learner autonomy through multiliteracy skills development in cross-institutional exchanges. Language Learning \& Technology, 16(3), 82-102.

Garcia Laborda, J., \& Author 1, S., (2016). Human Communicative Dialogic Practices in Content and Language-based Educational Interactions with Technology. International Journal of Educational Sciences, The Anthropologist. 25(3), 220-228. DOI: $10.1080 / 09720073.2016 .11892110$.

Gargallo, B., C. Campos \& Almerich. G. (2016). Learning to learn at university. The effects of an instrumental subject on learning strategies and academic achievement". Cultura y Educación 28 (4), 771-810. DOI: 10.1080/11356405.2016.1230293.

Grosbois, M., (2011). CMC-based projects and L2 learning: confirming the importance of nativisation. ReCALL 23(3), 294-310.

Guichon, N. (2009). Training future language teachers to develop online tutors' competence through reflective analysis. ReCALL, 21 (2), 166-185.

Guth, S., Helm, F. \& O'Dowd, R. (2012). University language classes collaborating online". Report on the integration of telecollaborative networks in european 
universities.

Retrieved

from:

http://coil.suny.edu/sites/default/files/intent_report_execsummary_june2012.pdf.

Hampel, R. (2009). Training teachers for the multimedia age: developing teacher expertise to enhance online learner interaction and collaboration Innovation. Language Learning and Teaching, 3(1), 35-50.

Hanesová, D., (2014). Development of critical and creative thinking skills in CLIL. Journal of Language and Cultural Education, 2(2), 33-51.

Hauck, M., (2010). Telecollaboration: At the interface between multimodal and intercultural communicative competence. In S. Guth \& F. Helm (Eds.), Telecollaboration 2.0, (pp. 219-244). Bern: Peter Lang.

Hautamäki, J., Arinen, P., Eronen, S., Hautamäki, A., Kupianien, S., Lindblom, B., Niemivirta, M., Pakaslahti, L., Rantanen, P., \& Scheinin, P. (2002). Assessing Learning-to-Learn: A Framework. Helsinki: Centre for Educational Assessment, Helsinki University / National Board of Education.

Hoskins, B. \& Fredriksson. U., (2008). Learning to Learn: What is it and can it be measured?. Scientific and Technical Report, Ispra: European Commission Joint $\begin{array}{llll}\text { Research } & \text { Centre. } & \text { Retrieved }\end{array}$ http://publications.jrc.ec.europa.eu/repository/bitstream/

Jara, C. A., Candelas, F. A., Torres, F., Dormido, S., and Esquembre, F. (2012). Synchronous collaboration of virtual and remote laboratories. Computer Applications in Engineering Education 20(1), 124-136.

Kleban, M. \& Author 3, M. C. (2016). Creating pedagogical knowledge through electronic materials in a telecollaboration project for pre-service teacher trainees. In M. Sanz, A. M. Levy, F. Blin \& D. Barr, (Eds.), WorldCALL: Sustainability and computer-assisted language learning (pp. 39-52). New York, NY: Bloomsbury 
Publishing.

McCormick, R. (2006). Learning how to learn: A view from the LHTL project England: Learning learn network meeting report. Ispra: CRELL/JRC.

Marsh, D., Mehisto, P., Wolff, D., \& Frigols, M. J. (2010). The European framework for CLIL teacher education. Graz: European Centre for Modern Languages, Council of Europe.

Martín, E. (1998). El papel del curriculum en la reforma educativa española, Investigación en la Escuela, 36, 31-47.

Meijer, J., Elshout-Mohr, M., \& van Hout-Wolters, B. (2001). An Instrument for the Assessment of Cross-Curricular Skills. Educational Research And Evaluation, 7(1), 79-107. http://dx.doi.org/10.1076/edre.7.1.79.6926.

Mesárosová, M., \& Mesáros, L. (2012). Learning to learn competency and its relationship to cognitive competencies of university students. Procedia on Social and Behavioral Sciences, 46, 4273-4278.

Moreno, A. (2002). La evaluación de las habilidades metacognitivas. In A. Marchesi \& E. Martín (Eds.), Evaluación de la educación secundaria (pp.33-42). Madrid: Fundación Santa María.

Moreno, A. (2006). Learning to learn: Learning to learn network meeting report. Ispra: CRELL/JRC.

Moreno, A. \& Martín, E. (2014). The Spanish approach to learning to learn. In Deakin Crick, R., K. Ren and C. Stringher (Eds), Learning to Learn International perspectives from theory and practice, (pp. 156-162). London: Routledge.

Muñoz-San Roque, I., Martín-Alonso, J. F., Prieto-Navarro, L. y Urosa-Sanz, B. (2016). Autopercepción del nivel de desarrollo de la competencia de aprender a aprender en el contexto universitario: propuesta de un instrumento de evaluación. Revista de 
http://dx.doi.org/10.6018/rie.34.2.235881.

Nieto, E., (2016). The Impact of CLIL on the Acquisition of the Learning to Learn Competence in Secondary School Education in the Bilingual Programmes of Castilla-La Mancha. Porta Linguarum 25(1), 21-34.

Novotná, J. \& Hofmannová. M., (2016). Teacher training for Content and Language Integrated Learning. Kubínová. Praha: Univerzita Karlova.

OECD, (2004). Learning for Tomorrow's World"- First Results from PISA, 2003. Paris: OECD.

O’Dowd, R., \& Ware, P. (2009). Critical issues in telecollaborative task design. Computer Assisted Language Learning, 22(2), 173-188. http://dx.doi.org/10.1080/09588220902778369.

Richards, J. C., (2005). Process-based approaches: content-based instruction and taskbased instruction: Communicative Language Teaching today. Cambridge: Cambridge University Press.

Schmid, E. C., \& Hegelheimer. V., (2014). Collaborative research projects in the technology-enhanced language classroom: pre-service and in-service teachers exchange knowledge about technology. ReCALL 26(3), 315-332.

Sharma, P., \& Hannafin, M. (2007). Scaffolding in technology-enhanced learning environments. Interactive Learning Environments, 15 (1), 27-46. DOI: $10.1080 / 10494820600996972$.

Sorenson, E. (2006). Learning- to-Learn: A Meta-Learning Perspective on Pedagogical Design of e-Learning: Learning to learn network meeting report. Ispra: CRELL/JRC.

Tanghe, S. \& Park, G. (2016). Build[ing] something which alone we could not have done 
in International collaborative teaching and learning in language teacher education. System, 57, 1-13. https://doi.org/10.1016/j.system.2016.01.002.

Vinagre, M. (2010). Teoría y práctica del aprendizaje colaborativo asistido por ordenador. Síntesis: Madrid.

Vinagre, M., (2016). Developing Key Competences for Life-Long Learning through Virtual Collaboration: Teaching ICT in English as a Medium of Instruction. Handbook of Research on Foreign Language Education in the Digital Age. Hershey, PA: Information Science Reference (IGI Global), 170-187.

Vinagre, M. (2017). Developing teachers' telecollaborative in online experiential learning. System, 64, 34-45.

Wang, Q. Woo, H. L. \& Zhao, J. (2009). Investigating critical thinking and knowledge construction in an interactive learning environment, Interactive Learning Environments, 17, 1, 95-104. Doi.org/10.1080/10494820701706320. 


\section{Appendices}

\section{Appendix 1. Organization of the study}

\begin{tabular}{|c|c|c|c|c|c|}
\hline Date & Means & $\begin{array}{r}\text { Task } \\
\end{array}$ & Grouping & Instrument & Product \\
\hline $\begin{array}{l}15-24^{\text {th }} \\
\text { Sept. }\end{array}$ & On-line & $\begin{array}{c}\text { 1st. Questionnaire: } \\
\text { LtL. Competence prior knowledge }\end{array}$ & Individual & On-line survey & $\begin{array}{l}\text { On-line } \\
\text { (Google } \\
\text { Docs.) }\end{array}$ \\
\hline $\begin{array}{l}24^{\text {th }} \\
\text { Sept. }\end{array}$ & Face to face & $\begin{array}{l}\text { Discussion: What is CLIL? } \\
\text { based on Bentley (2010) }\end{array}$ & Group & CLIL Questionnaire & Recordings \\
\hline $\begin{array}{l}28^{\text {th }} \\
\text { Sept. }\end{array}$ & $\begin{array}{l}1^{\text {st }} \text { Telecolla- } \\
\text { boration } \\
\text { CUCC-UPN }\end{array}$ & $\begin{array}{c}\text { Discussion: What is CLIL? } \\
\text { based on Bentley (2010) }\end{array}$ & $\begin{array}{c}\text { Inter- } \\
\text { university } \\
\text { groups }\end{array}$ & CLIL Questionnaire & Recording \\
\hline $\begin{array}{l}3^{\text {rd }} \\
\text { Dec. }\end{array}$ & Face to face & $\begin{array}{l}\text { CLIL Didactic unit / } \\
\text { Lesson plan design }\end{array}$ & $\begin{array}{l}\text { Class } \\
\text { groups }\end{array}$ & $\begin{array}{l}\text { Content Lesson } \\
\text { plan \& didactic unit }\end{array}$ & Wiki \& Blog \\
\hline $\begin{array}{l}3-10 \text { th } \\
\text { Dec. }\end{array}$ & On-line & $\begin{array}{l}\text { Delivery and analysis of the } \\
\text { Didactic unit/Lesson plan }\end{array}$ & $\begin{array}{l}\text { Inter- } \\
\text { university } \\
\text { groups }\end{array}$ & $\begin{array}{l}\text { Content Lesson } \\
\text { plan \& didactic unit }\end{array}$ & $\begin{array}{c}\text { e-mail } \\
\text { Wiki \& Blog }\end{array}$ \\
\hline $\begin{array}{l}\text { 10th. } \\
\text { Dec. }\end{array}$ & $\begin{array}{c}\text { 2nd } \\
\text { Telecolla- } \\
\text { boration } \\
\text { CUCC-UPN }\end{array}$ & $\begin{array}{l}\text { Discussion: } \\
\text { a) Analysis and proposal to } \\
\text { improve Bloom Taxonomy } \\
\text { (HOTs) in counterparts' units } \\
\text { b) Analysis and proposal to } \\
\text { enhance TICs in the classroom }\end{array}$ & $\begin{array}{l}\text { Inter- } \\
\text { university } \\
\text { groups }\end{array}$ & Word document & Recording \\
\hline $\begin{array}{l}\text { 10-22 } \\
\text { Dec. }\end{array}$ & On-line & $\begin{array}{c}2^{\text {nd }} \text { Questionnaire } \\
\text { L2L competence acquisition }\end{array}$ & Individual & On-line survey & $\begin{array}{c}\text { On-line } \\
\text { (Google Docs) }\end{array}$ \\
\hline $\begin{array}{l}\text { 22nd } \\
\text { Dec. }\end{array}$ & On-line & Auto-evaluation & Individual & Word document & $\begin{array}{c}\text { Discussion } \\
\text { Paper } \\
\end{array}$ \\
\hline
\end{tabular}


Appendix 2. Questionnaire Learning to Learn (European Commission, 2012)

\section{Why I learn}

Choose your current level from the list. Select 1 in your level and $\mathbf{0}$ in the other three levels

LEVEL 1. I learn when others urge, encourage, and persuade me. I feel secure when somebody helps me. When I work together with others, I observe more often how others are doing things.

LEVEL 2. I learn because I have to, but I eagerly learn only what I am interested in. I am self-confident when I have to complete easily understandable tasks. When I work together with others, I try to express my opinion.

LEVEL 3. I understand that learning is my duty and I therefore try to learn not only things that I am interested in. I usually feel self- confidant when I have to perform both usual and new non-complex tasks, and I am not afraid of making mistakes. When I work together with others, I often express my opinion and I help others whenever I can.

LEVEL 4. I learn eagerly and responsibly, because I like learning and understand that what I learn now will serve me in the future. I am self- confident, I am not afraid of challenges, and I welcome various new tasks. When working together with others, I not only learn from them but also help them eagerly and confidently.

What I learn (Setting objectives and planning activities)

Choose your current level from the list. Select 1 in your level and 0 in the other three levels

LEVEL 1. I set learning goals and plan learning activities when others help me. I manage to complete tasks on time when others urge me to.

LEVEL 2. I consult others to set my learning goals and plan my learning activities. I manage to complete certain tasks on time.

LEVEL 3. I try to set my learning goals autonomously and plan my learning activities. I usually manage to adhere to the schedule and complete tasks on time.

LEVEL 4. I set my learning goals autonomously. I successfully plan my learning and am therefore able to complete most tasks and tests on time.

How I learn (Organized and targeted learning activities)

Choose your current level from the list. Select 1 in your level and 0 in the other three levels

LEVEL 1. I use such learning methods and choose such information sources and learning tools which are offered to me by others.

LEVEL 2. With the help of others, I decide what learning method, learning tools, and information sources are best to perform a certain task.

LEVEL 3. I try to use different learning methods and I use various information sources. I try to obtain any required learning tools in advance.

LEVEL 4.I successfully use various learning methods and choose appropriate information sources. I obtain any required learning tools in advance.

I reflect on my progress (Reflection on learning activities and outcomes, and self-assessment) Choose your current level from the list. Select 1 in your level and 0 in the other three levels

LEVEL 1.When others help and encourage me, I observe my learning progress and sometimes listen to advice given to me and try to follow the advice

LEVEL 2. When others help me, I reflect on how and what I achieved in learning and in what areas and how I should improve.

LEVEL 3. I autonomously reflect on how and what I achieved in learning; others help me to plan in what areas and how I should improve.

LEVEL 4. I autonomously reflect on how and what I achieved in learning and plan in what areas and how I can improve 